\title{
The Var turbidite system (Ligurian Sea, northwestern Mediterranean)- morphology, sediment supply, construction of turbidite levee and sediment waves: implications for hydrocarbon reservoirs
}

\author{
Sébastien Migeon ${ }^{1,{ }^{*}}$, Thierry Mulder $^{2}$, Bruno Savoye $^{3}$ and Françoise Sage ${ }^{1}$
}

(1) Géosciences Azur, Observatoire de Villefranche, Port de la Darse, 06235 Villefranche-sur-Mer, France

(2) UMR 5805 EPOC, Université Bordeaux 1, Avenue des Facultés, 33400 Talence, France

(3) Laboratoire Environnements Sédimentaires, IFREMER, 29280 Plouzané, France

*: Corresponding author : sebastien.migeon@geoazur.obs-vlfr.fr

\begin{abstract}
:
The Var turbidite system is a small sandy system located in the Ligurian Basin. It was deposited during the Pliocene-Quaternary in a flat-floored basin formed during the Messinian salinity crisis. The system was fed through time by the Var and Paillon canyons that connect directly to the Var and Paillon rivers. It is still active during the present sea-level highstand. Two main mechanisms are responsible for gravity-flow triggering in the Var turbidite system: (1) mass-wasting events affect mainly the upper part of the continental slope, in areas where volumes of fresh sediment delivered by rivers are highest, and result from the under-consolidation state of slope sediments and earthquakes, and (2) high-magnitude river floods resulting from melting of snow and convective rainfall during fall and spring seasons, and generating hyperpycnal turbidity currents at river mouths when the density of freshwater transporting suspended particles exceeds that of ambient seawater. Failure- and flood-induced gravity flows are involved through time in the construction of the Var Sedimentary Ridge, the prominent right-hand levee of the Var system, and sediment waves. Processes of construction of both the Var Ridge and sediment waves are closely connected. Sandy deposits are thick and abundant in the eastern (downchannel) part of the ridge. Their distribution is highly constrained by the strong difference of depositional processes across the sediment waves, potentially resulting through time in the individualization of large and interconnected sand bodies.
\end{abstract}




\section{Introduction}

Deep-water turbidite environments have been widely studied throughout the world ocean since the early 70's, in various climatic and tectonic settings (Normark 1970; Shanmugam and Moiola 1988; Hesse and Rakofsky 1992; Droz et al. 1996; Piper and Normark 2001; Zaragosi et al. 2001). The understanding of the processes of construction and evolution of such sedimentary environments was closely connected to technical improvements. The use of new high-resolution exploration tools such as multibeam sonar, deep-towed side-scan sonar, high-resolution seismicreflection systems, drilling and long cores allow the more and more detailed identification, description and study of abyssal structures that were poorly understood until recent years. For many years, the study of turbidite systems has been strongly motivated by geohazards and also economical considerations, those systems being considered as preferential targets for offshore hydrocarbon prospecting. Sand-rich channel fills and lobes, forming potential continuous and interconnected sand bodies, have been intensively studied while levees, mainly considered as mud-rich features, have been more neglected.

Turbidite systems of contrasting size, morphology and sediment supply are well represented on North-Atlantic and Mediterranean French margins. This paper deals with the Var turbidite system located in the Ligurian Basin (northwestern Mediterranean; Fig. 1). It is a small sandy system, extending seaward of Nice (French Riviera) to the base of the continental slope of the Corsica island. The Var system was deposited during the Pliocene-Quaternary in a flat-floored basin formed during the Messinian salinity crisis (Savoye et al. 1993). In this paper, we present an overview of the latest results concerning the type and nature of gravity flows feeding the turbidite system and the nature and location of their deposits, the processes of construction of the Var Ridge and sediment waves and their complex interaction through time, the way thick sandy bodies constituting potential reservoirs can form on a turbidite levee.

\section{Method and data}

Results presented in this paper were obtained using a large dataset, including multibeam bathymetry and backscatter imagery, seismic-reflection profiles, $3.5 \mathrm{kHz}$ profiles, deep-towed side-scan sonar and cores collected since the early 80's over the whole turbidite system (Piper and Savoye 1993; Mulder et al. 1998; Migeon et al. 2001). Seismic-reflection profiles showed in this paper were recently collected during student cruises conducted every year by the Villefranche-surMer marine station onboard the R/V “Tethys II” (INSU-CNRS, France). The data were recorded by a $25 \mathrm{~m}$-long 6-channel streamer and the seismic source was a mini-GI air-gun fitting every 12$12.5 \mathrm{~m}$ at 140 bars, allowing for a 6-fold coverage. 
The seismic processing sequence applied to the numerical data included gain recovery, normal move out correction, stack, post-stack migration completed in the FK domain, and band-pass filtering. For the final plot, a coherency filter was applied to the data, as well as a dynamic equalization and a filtering in the FK domain.

\section{General morphology}

The continental shelf is very narrow (2-3 km) or absent offshore Nice and the Var river mouth. The steep continental slope is eroded by two main canyons, the Var Canyon and the Paillon Canyon, which connect directly to the Var and Paillon rivers and feed the Var turbidite system (Fig. 1).

The Var Canyon extends to 1600 m water depth. Its slope decreases from 11 to $8 \%$ and finally reaches $4 \%$ at the beginning of the Upper Valley on the turbidite system (Fig. 1). The canyon is floored with cobble and boulder waves, similar to features from fluvial braided systems (Savoye et al. 1988; Mulder et al. 1996). Fewer studies were conducted in the Paillon Canyon but similar coarse-grained waves have been already observed on the canyon floor (Malinverno et al. 1988), suggesting sediment supply and dynamic transport similar to the Var Canyon. The slope located between the two canyons is quite instable and intensively affected by gullying and small to large-scale mass-wasting events (Klaucke and Cochonat 1999).

The Upper Valley extends $12 \mathrm{~km}$ southeastward from the confluence of the two canyons to a water depth of $2000 \mathrm{~m}$, its slope decreasing from 4 to $2 \%$. Its walls are eroded over the first $60 \mathrm{~m}$ above the valley floor and highly dissected by small retrogressive failure events. It is filled with gravel waves and sandy deposits (Piper and Savoye 1993). Small terraces, 10 to $30 \mathrm{~m}$ height, are built on both side of the valley axis by small-scale overflowing processes resulting from thin sandy or thicker diluted currents flowing downvalley.

The Middle Valley (Fig. 1) begins at a sharp bend to the left. It extends $50 \mathrm{~km}$ eastward to a water depth of 2500 m near a continuous line of salt diapirs (the Diapir Wall), at which the Valley bends to the southeast. Its slope decreases from 2 to $0.3 \%$. Valley axis is divided into two branches separated by a median ridge. The Valley is floored with gravel waves (wavelength up to $80 \mathrm{~m}$ ) alternating with silty and sandy deposits. Erosional scours commonly affected valley-fill deposits. They decrease in depth (from 10-15 m to 1-3 m) and increase in width (from 200-400 m to $800-1000 \mathrm{~m}$ ) and spacing (from 700-1500 m to $3000 \mathrm{~m}$ ) downvalley (Savoye et al. 1988; Migeon et al. 2001). The northern or left-hand levee of the Middle Valley is low and discontinuous. The southern or right-hand levee is characterised by an elongate prominence called 
the Var Sedimentary Ridge (Piper and Savoye 1993). It has an asymmetrical cross-section with a steeper and shorter northern (inner) flank and a flatter and longer southern (outer) flank. Its height decreases, from the west to the east, from $400 \mathrm{~m}$ to less than $30 \mathrm{~m}$, resulting in progressively lower relief between the valley floor and the levee crest. In the eastern part of the Ridge, the boundary between the levee and the valley is quite gradual whereas upstream, steep walls separate the levee from the valley. The more or less continuous basal erosion of the inner flank of the Ridge caused surficial failures sliding into the Valley axis. A field of sediment waves partly covers the outer flank of the Ridge, from 2000 to 2600 m depth (Migeon et al. 2000). The Western Spillover Channel, 2-4 km wide and 50-100 m deep, cuts through the western part of the Ridge and joins the Cannes Valley (Fig. 1).

The Lower Valley extends $100 \mathrm{~km}$ southeastward from the Diapir Wall, feeding a sandy distal lobe, at a water depth of $2700 \mathrm{~m}$ at the base of the northwestern slope of Corsica (Savoye et al. 1995, 1998; Fig. 1). The Lower Valley slope decreases from 0.3 to $0.1 \%$. Discontinuous and partly eroded levees, 10 to $40 \mathrm{~m}$ height, built along the valley. Valley axis is floored with sandy deposits (Savoye et al. 1993).

The distal lobe built in the deep basin, at the mouth of the Lower Valley. It is $80 \mathrm{~km}$ long and $40 \mathrm{~km}$ wide. Its seismic architecture is homogeneous and mostly consists of sand bodies of "sheet-like" geometry (Savoye et al. 1995, 1998).

\section{Paleogeographic evolution}

The paleogeographic evolution of the Var turbidite system is dominated by the evolution of its channel-levee system. The paleogeographic evolution from early Pliocene to present has been illustrated in a series of maps, and regional seismic reflectors have been identified (Savoye et al. 1993). The chronological succession of events is constrained by four regional reflectors (I-IV) recognised over the whole basin (Savoye et al. 1993). After the rapid basal Pliocene TB 3.4 transgression (Haq et al. 1987), the Var valley excavated during the Messinian became a ria on land where coarse material was trapped. Only hemipelagic clays accumulated in the more distal parts of the rias (Clauzon et al. 1990) and probably in the open sea as well (Savoye et al. 1993). The following lowstand may have allowed a canyon and levee-bordered fan-valley system to develop downslope from the old Messinian canyon. This early valley then prograded straight south towards the Ligurian abyssal plain (C2-3 in Fig. 2).

By the time of the regional Reflector II, the main Var fan valley had shifted position a few kilometres to the east (channel C4 in Fig. 2). A smaller channel was also present beneath the 
present position of the lower Var fan valley, and was probably fed either by spillover from the main Var valley, or by the La Roya canyon (Fig. 2).

Between 3 and 1.5 Ma, shortly before formation of regional Reflector III, the proposed spillover channel from the main Var valley became established as the main Var fan valley through avulsion, and the old fan valley to the south was abandoned and filled with levee sediments. This new fan valley, which lies beneath the northern edge of the Var Sedimentary Ridge, built a prominent levee on its south side. Subsequently, this channel switched to a new position further north (channel C5-6 in Fig. 2). The formation of giant sediment waves began at this time. Since the time of development of regional Reflector III, there has been a gradual northward shift of the main Var Channel.

\section{Sediment supply and trigger mechanisms}

Two main mechanisms are responsible for gravity-flow triggering in the Var turbidite system: mass-wasting events and river floods.

Mass-wasting events mainly affect the upper part of the continental slope, in areas close to the Var and Paillon river mouths, where volume of fresh sediment delivered by rivers is the highest. Small-scale failures are mainly located near the shelf break; they are the most abundant type of failures and are restricted to the uppermost layers (up to $10 \mathrm{~m}$ ) of slope sediment (Migeon et al. 2005). Larger-scale failures are located deeper on the slope and they affect deposits over greater thickness (up to 40-50 m; Migeon et al. 2005). Smaller failures mainly result from the under-consolidation state of slope sediment during periods of high sedimentation rate, while the triggering of larger failures probably requires an external constraint such as an earthquake-induced acceleration of the seafloor. The best-known example of such large-scale failure is the so-called “1979 Event” (Piper and Savoye 1993; Mulder et al. 1997). On October $16^{\text {th }} 1979$, at about 2 pm, a failure involving about $8 \times 10^{6} \mathrm{~m}^{3}$ of material occurred at shallow water depth during infilling operations related to the construction of the new Nice harbour. Since 1975, at least $25 \times 10^{6} \mathrm{~m}^{3}$ of aggregates were deposited on the narrow shelf, at a water depth ranging from 10 to $15 \mathrm{~m}$, to increase the surface of the airport in a seaward direction. The failure affected both underconsolidated silty-clayey deposits of the upper continental slope and some of the landfill aggregates. This event was very sudden and the extension of the airport slided in the sea within a time interval of few minutes. At the same time, witnesses located onshore observed a sea-level fall of tens of metres and eight minutes later, three successive waves, 2-3 m height, broke along the coastline between Nice and Antibes, causing damage and people death. This tsunami was related to the plunging of surficial seawater swept away by the downslope movement of sliding sediment. 
Then, 4 h 45 min and 8 h 50 min later, two submarine cables were broken in the Ligurian Basin, the first one in the eastern part of the Var Ridge and the second one crossing the Lower Valley, at about $80 \mathrm{~km}$ and $107 \mathrm{~km}$ respectively from the failure area. In situ observations and modelling results showed that the slide transformed into a debris flow then in a surge that reached the Var Ridge and probably the distal lobe (Mulder et al. 1997). The surge was responsible for cable breaks. Velocity of the flow was estimated to $30-40 \mathrm{~m} / \mathrm{s}$ in the Var Canyon and Upper Valley (Mulder et al. 1997), then to less than $10 \mathrm{~m} / \mathrm{s}$ in the Middle Valley (Piper and Savoye 1993), and about 4-5 m/s in the eastern part of the Ridge (Migeon et al. 2001) where the first cable was broken. The total volume of deposit resulting from this event was estimated to $15 \times 10^{6} \mathrm{~m}^{3}$ (Piper and Savoye 1993), evidencing the strong erosive power of such a flow. In the case of the 1979 event, the landfill construction activity alone seems to explain the failure. Nevertheless, the Ligurian Basin has been frequently affected by earthquakes (four historical earthquakes in 1564, 1644, 1817 and 1887 with magnitude ranging from VIII to $\mathrm{X}$ on Mercalli Scale, and six earthquakes with magnitude ranging from 4 to 6 since 1963), and three historical tsunamis (1564, 1817 and 1887) affected the Nice-Menton area. Based on the 1979-event experience, earthquakes might have generated tsunamogenic failures on the Ligurian slope in the past. So, the 1979 event may be a preview of what could happen in the case of a large earthquake-induced failure, triggered on the upper slope, near the coastline.

River flood generating hyperpycnal turbidity current is also a common process in the Var system (Mulder et al. 1998). The Var and Paillon rivers are small mountain-supplied rivers that experience violent flash floods every year, during fall and spring times, as a result of snow melt and convective rainfall. The average water discharge of the Var river, about $50 \mathrm{~m}^{3} / \mathrm{s}$, can increase tenfold during floods, and suspended sediment concentration can reach tens of $\mathrm{kg} / \mathrm{m}^{3}$. Hyperpycnal turbidity currents are turbulent flows generated at river mouth when the density of fresh water transporting suspended particles exceeds the density of the ambient sea water. Depending on salinity and temperature of sea water near the mouth of the Var river, critical concentration of suspended particles needed to produce hyperpycnal flows should be about 40-44 $\mathrm{kg} / \mathrm{m}^{3}$ and critical river discharge should range from a threshold value of $620 \mathrm{~m}^{3} / \mathrm{s}$ to a maximum value of $1250 \mathrm{~m}^{3} / \mathrm{s}$ (Mulder et al. 1996). From the rating curve of the Var river, the return period of short-duration (several minutes to several hours) and one day-long hyperpycnal events could be 2 and 5 years respectively (Mulder et al. 1998). So, hyperpycnal events are thought to be generated very frequently. In November 1994, the record of water discharge and concentration of suspended particles allowed the study of one of these flash floods. Discharge at the river mouth 
reached a maximum value of $4000 \mathrm{~m}^{3} / \mathrm{s}$ that probably generated a hyperpycnal flow 20 hours in duration and the transport of $18 \times 10^{6} \mathrm{~m}^{3}$ of sediment to the deep turbidite system over a period of 18 hours (Mulder et al. 1996). This volume of transported particles represents more than 10 times the mean annual volume of particles delivered at the Var river mouth and 1.5 times the volume of upper slope sediment initially involved in the 1979 event. Hyperpycnal currents constitute a major mechanism of rapid particle transfer from the continent to the deep basin. From the record of instantaneous water discharge measurements at the mouth of the Var river, six hyperpycnal currents may have been triggered since 1977 (Mulder et al. 2001b).

\section{The Var Sedimentary Ridge}

The Var Ridge is probably the best-known environment of the Var system. It constitutes a thick accumulation that recorded through time processes related to the construction of the whole system and that probably affected the local evolution and migration of the channel/levee system.

\subsection{Internal architecture}

The framework of the Var Ridge is described using two seismic-reflection profiles exhibiting typical succession of seismic facies. Profile V11 follows the crest of the Ridge (Fig. 3). A succession of continuous, low to moderate amplitude reflections, typical of levee deposits and spill-over, is observed between regional reflectors II and III, immediately above channel C4 deposits (corresponding thus to Channel C5 activity). From reflector III to the top of the Ridge, the continuous reflections are divergent from west to east along the levee, implying that sediment deposition rate increases substantially eastward (Fig. 3). Many spillover channels cut through the levee crest in the western part of the Ridge (Fig. 3). Profile $030 R 103$ (Fig. 4) is transverse to the crest of the Ridge across the middle part of the levee. The succession of continuous, parallel low to moderate amplitude reflections, corresponding to the Var Ridge deposits, is immediately on top of discontinuous higher amplitude reflections corresponding to channel C4 deposits, suggesting the construction of the Ridge started very rapidly after the northward shift of channel C4. Some reflectors can be correlated across the whole Ridge, showing its thickness decreases rapidly southward with increasing distance from the Middle Valley. This suggests that sediment deposition is highest near the crest of the Ridge, then decreases rapidly 2-3 km beyond the Ridge crest and becomes more or less uniform towards the southern distal part of the Ridge. Near the valley, the Ridge deposits were also strongly affected by erosional processes and faulting (Fig. 5). A sharp erosional surface is correlated with the top of channel C5-6 (Fig. 5). That surface deeply incised previous deposits over 100-200 m and was probably generated after the channel C5-6 started to migrate northward, to its present location. Then, the incisions have been gradually filled 
by levee deposits once the channel established in its present location. Small to large-scale failures also affected surficial deposits in the western part of the Ridge (Fig. 5). A few kilometres southward, down the Var Ridge flank, sediment accumulation dominates as shown by the presence of large sediment waves (Figs 4 and 6). Sediment waves developed immediately on top of channel C4 deposits. Their initiation was synchronous with the first stage of construction of the Ridge, just after the channel shift C4/C5-6 (Fig. 6). Farther southwards, the distal deposits of the Ridge are strongly affected by salt diapirs (Fig. 4).

\subsection{Nature of gravity-flow deposits}

Three main types of gravity-flow deposits were recognised at various locations along the Ridge:

- turbidite deposits resulting from the spill-over of turbidity currents flowing into the Middle Valley. They consist of normally graded silty to sandy layers showing sharp or erosive basal contact and gradational upper contact with hemipelagic intervals. Coarser-grained turbidites classically exhibit Ta, Tb and Tc divisions of the Bouma sequence (Migeon et al. 2001). Finergrained turbidites consist of 4-5 silty laminae, a few millimetres thick, that thin and fine upward (Migeon 2000).

- hyperpycnite deposits resulting from activity of hyperpycnal flows (Mulder et al. 2002). Because hyperpycnal currents are turbulent flows generated at river mouth during exceptional floods, they will remain waxing as long as the discharge increases during river rise and then will become waning during river fall as discharge and suspended particle concentration decrease. Typical hyperpycnite deposits will thus exhibit a basal inverse grading as the flow accelerates and an upper normal grading as the flow decelerates (Migeon et al. 2001; Mulder et al. 2001a). Horizontal laminae and climbing ripples are common (Migeon et al. 2001), showing that sedimentation occurs continuously from suspension and that flows have a high suspended particle concentration. Size of suspended particles varies from silt to medium sand.

- inversely graded sandy layers, with fine-sediment content of 10-20\% constituting a matrix and scattered mud clasts, reflect deposition from the sandy basal laminar layer of gravity flows (Migeon et al. 2001). On the Var Ridge, such a dynamic characterises flows in which turbulence is progressively suppressed because particle concentration increases through time and results in the formation of an increasingly thick laminar and viscous basal layer. The increased concentration is linked both to the erosion of the sea-floor on the levee and to the decrease of the current thickness because of the change from subcritical to supercritical conditions (Migeon et al. 2001). 


\subsection{Surficial sediment distribution}

Many tens of Kullenberg piston cores have been collected on the Ridge since the early 80's. A compilation of these data (Migeon et al. 2000) allowing reconstruction of the spatial distribution of sediment throughout the levee is summarized on Fig. 7. Along the Ridge, deposits coarsen eastward with a gradual change from interbedded laminated mud and silt and laminated mud with basal silt or sand layer in the western part, to centimetric fine-sand turbidites in the middle part and well-developed medium-sand turbidites up to $20 \mathrm{~cm}$ thick and showing erosive bases in the eastern part. Hyperpycnite deposits 5 to $15 \mathrm{~cm}$ thick are mainly observed in the middle and eastern parts of the Ridge. Deposits $40 \mathrm{~cm}$ thick from the sandy basal laminar layer of gravity flows are only observed in the eastern part the Ridge where crest elevation less than $30 \mathrm{~m}$ and the channel wall is gently dipping, allowing both the lowermost and upper part of gravity flows to overspill the levee. In the cores, the sand content gradually increases eastward as well, from less than $5 \%$ to as much as $60 \%$. The sedimentation rate in the western part of the Ridge is about $17 \mathrm{~cm} / \mathrm{ka}$ since the last glacial period (Piper and Savoye 1993) and is probably three or four times higher on the eastern part of the Ridge (based on seismic-reflection data). Such downstream increase of silt-sand supply along a turbidite levee is not uncommon and also described, among others, in the Amazon system (Manley et al 1997; Pirmez and Imran 2003), the Cap-Ferret system (Cremer 1983) and the Zaire system (Migeon et al. 2004).

\section{Sediment waves}

Sediment waves are giant sedimentary structures built by gravity flows that spill out of the Middle Valley and spread sediment over the Ridge (Migeon et al. 2000). Their amplitudes range from less than $5 \mathrm{~m}$ to up as much as $60 \mathrm{~m}$, with an average of about $20 \mathrm{~m}$. Their wavelengths range from 600 to $7000 \mathrm{~m}$, with an average of about $2200 \mathrm{~m}$. They migrate upslope and upcurrent, in a manner similar to fluvial antidunes (Normark et al. 1980). Today, the wave field covers a $1500 \mathrm{~km}^{2}$ area of the Var Ridge. Through the field, the number of sediment waves decreases gradually while their wavelength and amplitude gradually increase from west to east with decreasing height of the Ridge above the valley floor. Wave crests are subparallel and are generally oriented obliquely (about $45^{\circ}$ ) to the Middle Valley and to the crest of the Ridge, which is consistent with a construction by gravity flows over-spilling from the valley (Migeon et al. 2000).

Three different sediment-wave geometries were recognised at particular location on the Ridge (Migeon et al. 2000). They are linked with the evolution of the height of the Ridge, the local gradient slope, and the type of gravity-flow deposits: 
- in the eastern part of the Ridge, where levee height above the valley floor is less than $30 \mathrm{~m}$ and local slope is $3-4 \%$, sediment waves always exhibit through time an asymmetrical crosssection: their upstream flanks are steeper and shorter than their downstream flanks. The waves are still active today and migrate upslope toward the Middle Valley (Fig. 8). Some waves finally reached the valley and now migrate within it, overlapping sandy valley-fill deposits (Migeon et al. 2001). The asymmetry and upslope migration of the waves results from a major asymmetry of deposits between the upstream and downstream flanks. Deposits are 2-3 times thicker on the upstream flanks, suggesting sediment deposition occurs mainly on upstream flanks, whereas low deposition, bypassing, or erosion predominate on downstream flanks. In this area, thick sandy deposits (up to $40 \mathrm{~cm}$ ) alternate vertically with muddy intervals,

- in the middle part of the Ridge, where levee height ranges between 180 and $80 \mathrm{~m}$ and local slope decreases from 6-7\% to $2 \%$ downlevee, sediment waves have "inverse” asymmetrical crosssection: their upstream flanks are smoother and longer than their downstream flanks (Fig. 6). This morphology results from the gradual filling up of the upstream troughs and flanks of older asymmetrical sediment waves. Such geometry emphasises the predominance of the vertical aggradation trend. Deposits consist of numerous and thin sandy/silty turbidites $(1-5 \mathrm{~cm}$ thick) alternating with thick muddy turbidites,

- in the western part of the Ridge, where levee height ranges from 360 to $200 \mathrm{~m}$ and local slope decreases from $6-7 \%$ to $2 \%$ downlevee, sediment waves always exhibit through time a symmetrical cross-section (Migeon et al. 2000). Sediment deposition is homogeneous along sediment waves, suggesting the deposition of draping sediments. Such geometry characterises a more active vertical aggradation than an upslope progradation. The waves are poorly developed, appearing as low undulations on the sea floor. Deposits consist of thick muddy turbidites interbedded with sand or silt laminae.

Thus, except in the middle part of the Ridge where the geometry of the waves gradually changes from asymmetrical to "inverse" asymmetrical (Fig. 6), the processes or factors that control sediment-wave distribution on the Var Ridge remained broadly similar through time. The east-west distribution of sediment-wave geometries is mainly constrained by the spill-over energy and the sediment supply (Migeon et al. 2000). Considering the change in deposits and elevation of the crest along the Ridge, asymmetrical prograding sediment waves built in the eastern part of the Ridge where sediment supply is the highest and where spill-over energy is high and most of the gravity-flows may experience supercritical conditions (Migeon et al. 2001); symmetrical aggrading sediment waves built in the western part of the Ridge where sediment supply is lower 
and deposits suggest low or moderate energy spill-over and gravity flows are subcritical. The change from prograding asymmetrical to aggrading "inverse" asymmetrical waves in the middle part of the Ridge reflects a gradual decrease of sediment supply and spill-over energy through time because of the gradual increase of the elevation of the Ridge in that area (Migeon et al. 2000).

Detailed process of sediment-wave construction and migration through time was enlightened from three cores collected on the upstream flank, crest and downstream flank of a single asymmetrical prograding sediment wave located in the eastern part of the Ridge (Migeon et al. 2001). At the scale of the three cores, the sand content decreases from $60 \%$ to $35 \%$ between the upstream and downstream flanks, and the individual sandy layers are always the thickest on the upstream flank then their thickness decreases rapidly to a few centimetres on the crest and a few millimetres on the downstream flank. These facts confirm that sediment deposition mainly occurs on the upstream flank and decreases gradually on the downstream flank. It might indicate that gravity-flow energy is too high on the crest and the downstream flank to allow high rates of sediment deposition. However, erosional features are more frequent in cores collected on the crest and the downstream flank, indicating the increase of flow energy in these parts of the wave compared to the upstream flank. This suggests that locally, the basal sandy laminar part of the flows must decelerate at the base of the upstream flank because of the abrupt change of the slope gradient, allowing high rate of sand deposition, and then re-accelerate near the crest because of the decrease in cross-sectional area of the flow, allowing less deposition or even erosion on the crest and downstream flank (Migeon et al. 2001).

The way sediment waves are initiated is still poorly understood. In the middle part of the Ridge (Fig. 6), sediment waves clearly developed on top of chaotic intervals corresponding to a former position of the channel (C4) or on top of salt diapir-induced deformation. The surface on which sediment waves initiated is quite rough and presents wavy topography that acted as a template allowing their initiation. In the eastern part of the Ridge, a similar large-scale preexisting topography was never observed on high-resolution seismic-reflection profiles and sediment waves initiated on a flat surface (Fig. 8). Here, one can speculate that sediment-wave initiation is the result of the interaction between turbulent flows and a loose sea-floor. Turbulent vortices within the flows or alternation of burst and sweep events at the base of fully turbulent flows might create alternation of eroded and non-eroded surfaces leading to the formation of a more or less small-scale wavy sea-floor that could provide a support for the sediment-wave initiation (Migeon et al. 2001).

\section{Discussion and conclusion}


Impact of failure- and flood-induced sediment transport is well-preserved in the sediment record over the whole Var system. The recent study of a core collected on a terrace 20-30 m height near the base of the Upper Valley revealed the presence of 13 deposits resulting from hyperpycnal flows, 3 turbidite deposits (including the 1979 event) and 10 hemipelagite intervals, representing 1.2 metres of sediment deposited during the last 100 years (Mulder et al. 2001b). Thus, recent processes of sediment transport and deposition were mainly dominated by hyperpycnal-flow activity, $70 \%$ of the deposits resulting from flood-induced flows while only $5 \%$ result from failure-induced turbidity currents, and 25\% being hemipelagites. The absence of continental shelf and the direct connection of the canyon heads to the Var and Paillon rivers also suggest that hyperpycnal currents were probably regularly triggered during the last glacial periods. They allowed more or less continuous sediment supply to the turbidite system, whatever the fluctuations of sea-level might be. The rapid construction of the prominent Var Ridge during the last 900 kyrs required through time such constant and regular supply. During the late Pleistocene and Holocene times, failure-induced turbidity currents were as common as hyperpycnal flows (Migeon et al. 2001).

The progressive northeastward migration of channels, that occurred on the Var fan through the Quaternary, has resulted in development of a left hook of the right-hand levee. This evolution of the Var Ridge has given the entire system an unusual morphology and evolution. Seismicreflection profiles along the Var Ridge suggest that levee grew by down-channel progradation, rather than steady and uniform aggradation above regional Reflection III along the entire levee. This process is evidenced by the gradual eastward thickening of the interval between Reflections III and IV and between Reflection IV and the seafloor (Fig. 3). The rapid down-channel growth of the Ridge correlates with the development of sediment waves. The northward migration of the Ridge through time is more pronounced in its eastern part where upslope progradation and size of sediment waves are the highest (Fig. 8), whereas Ridge aggradation is most conspicuous where sediment waves aggrade (western and middle parts). This pattern of development emphasises the complexity of the relationships existing between the temporal evolution of the Ridge and that of the sediment waves: prograding sediment waves located near the valley or directly migrating within the valley gradually become high enough to confine the lowermost part of gravity flows that can no more overflow; the energy of spill-over thus gradually decreases in this part of the Ridge; sediment waves can no longer prograde but start to aggrade (Fig. 6) and thus contribute to Ridge aggradation. Then, new prograding sediment waves develop further east and contribute to eastward and northward Ridge migration (Migeon et al. 2000). 
Along the Var Sedimentary Ridge, the sand content and grain-size of deposits gradually increase eastward (Fig. 7). This change illustrates an important paradox of turbidity-current deposition along turbidite levees, in which the trend of the deposit coarseness is opposite to the classical model. Pirmez and Imran (2003) addressed a similar problem along the levees of the Amazon fan and evidenced a control of the topography on the grain size of the overspilled portion of the flows. Levee formation is generally explained by a process of continuous flow stripping of the upper portions of turbidity currents (Komar 1973; Piper and Normark 1983), which always carry the finer-grained portion of the sediment load (Stacey and Bowen 1988). Thus, fine material is continuously deposited on the Ridge, while coarse material is concentrated in the lower part of the flows and remains confined within the Middle valley, allowing the deposition of coarser material farther downstream. Gravity flows that are sufficiently large to overflow the Var Sedimentary Ridge likely erode and incorporate sand from the floor of the Middle Valley (Savoye et al. 1988) and one can suppose that those gravity flows thus become coarser downstream. When the height of the Ridge becomes too low to confine the flows, the lowermost part of the channelised currents overtops the Ridge crest, allowing the deposition of thick coarser layers in the eastern part of the Ridge. The distribution and geometry of these sandy deposits are highly constrained by the sediment-wave geometry and their evolution through time (Migeon et al. 2001). Sand deposition mainly occurs on the upstream flank of the sediment waves. Because of the upslope progradation of the sediment waves, the sandy deposits of the upstream flanks are gradually overlain with finer deposits from the crests and the downstream flanks. Thus, each sediment wave can represent a single potential reservoir of several $\mathrm{km}^{3}$. The volume and geometry of the potential reservoir will change according to the size of sediment waves, their proximal or distal location on the Ridge, and their progradation rate. Several superposed fossil sediment waves are observed on the seismic-reflection lines. So, each sediment wave can be connected to former sediment waves which can form interconnected sandy bodies.

\section{Acknowledgements}

The authors thank captain and crew of the R/V Téthys II, and C. Pirmez and M. Cremer for their constructive review of the paper. 
References

Cremer M (1983) Approches sédimentologique et géophysique des accumulations turbiditiques. L'éventail profond du Cap-Ferret (Golfe de Gascogne), La série des grès d'Annot (Alpes de Haute Provence): $3^{\text {rd }}$ cycle Thesis, University Bordeaux I, France, 344 p.

Clauzon G, Suc J-P, Aguilar J-P, Ambert P, Cappetta H, Cravatte J, Drivaliari A, Domenech R, Dubar M, Leroy S, Martinell J, Michaux J, Roiron P, Rubino J-L, Savoye B, Vernet J-L (1990) Pliocene Geodynamic and Climatic Evolutions in the French Mediterranean Region. Paleontologia di Evolucio, Memoria Especial n², 132-186.

Droz L, Rigaut F, Cochonat P, Tofani R (1996) Morphology and recent evolution of the Zaire turbidite system (Gulf of Guinea). GSA Bulletin 108(3): 253-269.

Haq BU, Hardenbol J, Vail PR (1987) Chronology of fluctuating sea levels since the Triassic. Science 235: 1156-1167.

Hesse R, Rakofsky A (1992) Deep-sea channel/submarine-yazoo system of the Labrador Sea: a new deep-water facies model. AAPG Bulletin 76(5): 680-707.

Klaucke I, Cochonat P (1999) Analysis of past seafloor failures on the continental slope off Nice (SE France). Geo-Marine Letters 19: 245-253.

Komar P (1973) Continuity of turbidity current flow and systematic variations in deep-sea channel morphology. Geological Society of America Bulletin 84: 3329-3338.

Malinverno A, Ryan WBF, Auffret GA, Pautot G (1988) Sonar images of the Path of Recent Failure Events on the Continental Margin off Nice, France. Spec. Pap. Geol. Soc. Am. 229: $59-75$.

Manley PL, Pirmez C, Busch W, Cramp A (1997) Grain-size characterization of Amazon Fan deposits and comparison to seismic facies units. In: Flood, R.D., Piper, D.J.W., Klaus, A., and Peterson, L.C., (eds.) Proceedings of the Ocean Drilling Program, Scientific Results 155, pp 35-52.

Migeon S (2000) Dunes géantes et levées sédimentaires en domaine marin profond: Approches morphologique, sismique et sédimentologique: Ph.D. Thesis, University Bordeaux 1, France, 288 p. 
Migeon S, Savoye B, Faugères J-C (2000) Quaternary development of migrating sediment waves in the Var deep-sea fan: distribution, growth pattern and implication for levee evolution. Sedim. Geol. 133: 265-293.

Migeon S, Savoye B, Zanella E, Mulder T, Faugères J-C, Weber O (2001) Detailed seismicreflection and sedimentary study of turbidite sediment waves on the Var Sedimentary Ridge (SE France): significance for sediment transport and deposition and for the mechanisms of sediment-wave construction. Marine and Petroleum Geology 18: 179-208.

Migeon S, Savoye B, Babonneau N, Spy-Andersson F-L (2004) Processes of sediment-wave construction along the present Zaire deep-sea meandering channel: role of meanders and flow-stripping. Journal of Sedimentary Research 74(4): 580-598.

Migeon S, Garziglia S, Sage F, Sardou O (2005) Submarine landslides in the Ligurian basin: Impact of sediment supply, earthquakes and salt tectonic. In : Association of the French Sedimentologits Meeting, Presqu'île de Giens, Book of Abstracts.

Mulder T, Migeon S, Savoye B, Faugères J-C (2001a) Inversely graded turbidite sequences in the deep Mediterranean: a record of deposits from flood-generated turbidity currents? GeoMarine Letters 21: 86-93.

Mulder T, Migeon S, Savoye B, Jouanneau J-M (2001b) Twentieth century floods recorded in the deep Mediterranean sediments. Geology 29(11): 1011-1014.

Mulder T, Migeon S, Savoye B, Faugères J-C (2002) Inversely-graded turbidite sequences in the deep Mediterranean : a record of deposits from flood-generated turbidity currents ?: Reply to comments by S. Shanmugam. Geo-Marine Letters 22: 112-120.

Mulder T, Savoye B, Piper DJW, Syvitski JPM (1998) The Var submarine sedimentary system: understanding Holocene sediment delivery processes and their importance to the geological record. Geol. Soc. (London) Spec. Publ. 129: 146-166.

Mulder T, Savoye B, Syvitski JPM (1997) Numerical modelling of a mid-sized gravity flow: the 1979 Nice turbidity current (dynamics, processes, sediment budget and seafloor impact). Sedimentology 44: 305-326.

Mulder T, Savoye B, Syvitski JPM, Parize O (1996) Des courants de turbidité hyperpycnaux dans la tête du canyon du Var? Données hydrologiques et observations de terrain. Oceanol. Acta 20: 607-626.

Normark WR (1970) Growth patterns of deep-sea fans. AAPG Bulletin 54(11): 2170-2195. 
Normark WR, Hess GR, Stow DAV, Bowen, AJ (1980) Sediment waves on the Monterey Fan levee: a preliminary physical interpretation. Mar. Geol. 37: 1-18.

Normark WR, Piper DJW, Stow DAV (1983) Quaternary development of channels, levees, and lobes on middle Laurentian Fan. AAPG Bulletin 67: 1400-1409.

Piper DJW, Normark WR (1983) Turbidite depositional patterns and flow characteristics, Navy Submarine Fan, California Borderland. Sedimentology 30: 681-694.

Piper DJW, Normark WR (2001) Sandy fans-from Amazon to Hueneme and beyond. AAPG Bulletin 85(8): 1407-1438.

Piper DJW, Savoye B (1993) Processes of late Quaternary turbidity current flow and deposition on the Var deep-sea fan, north-west Mediterranean Sea. Sedimentology 40: 557-582.

Pirmez C, Imran J (2003) Reconstruction of turbidity currents in Amazon Channel. Marine and Petroleum Geology 20: 823-849.

Savoye B, Piper DJW, Droz L (1993) Plio-Pleistocene evolution of the Var deep-sea fan off the French Riviera. Mar. Petrol. Geol. 10: 550-571.

Savoye B, Cochonat P, Piper DJW, Nelson H, Voisset M, Droz, L (1995) Late Quaternary turbidity current activity: the Var deep-sea fan case study (Northwestern Mediterranean). In: I.A.S. $16^{\text {th }}$ Regional Meeting of Sedimentology, Aix-les-Bains, Book of Abstracts, p. 132.

Savoye B, Nelson H, Unterseh S, Piper DJW, Rehault, JP (1998) The Var Fan distal lobe (Ligurian Sea, Mediterranean): side-scan facies, seismic architecture, nature of deposits. In: I.A.S. $15^{\text {th }}$ International Sedimentolgical Congress, Alicante, Book of Abstracts, p. 701.

Savoye B, Voisset M, Cochonat P, Auffret GA, Bourillet J-F, Droz L, Ollier G, Coutelle A, Le Cann C, Auzende J-M, Robert S (1988) «Le canyon du Var»: case study of a modern active proximal channel. AAPG Mediterranean Basins Conference, Nice, France, October 1988.

Shanmugam G, Moiola RJ (1988) Submarine fans: characteristics, models, classification and reservoir potential. Earth Science Reviews 24: 383-428.

Stacey MW, Bowen AJ (1988) The vertical structure of density and turbidity currents: theory and observations. Journal of Geophysical Research 93: 3528-3542. 
Zaragosi S, Le Suave R, Bourillet JF, Auffret GA, Faugères JC, Garlan T (2001) The deep-sea Armorican depositional system (Bay of Biscay), a multiple source, ramp model. Geo-Marine Letters 20: 219-232. 
Figure 1 - Location of the Var turbidite system within the Ligurian basin (contour interval in metres) with the name of the main features.

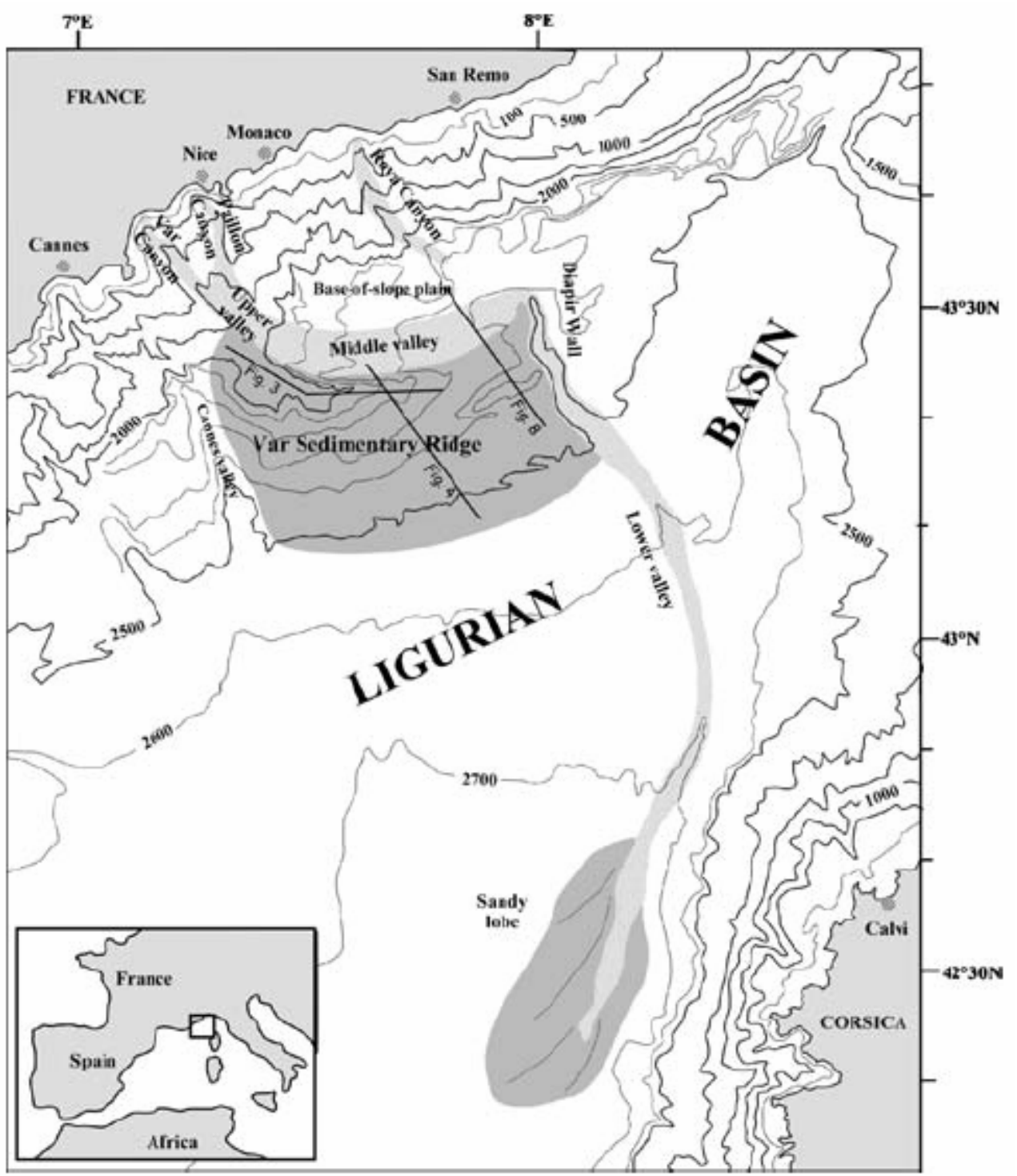


Figure 2 - Schematic map illustrating the paleogeographic evolutions of the Var system (modified from Savoye et al., 1993). C2-3, C4 and C5-6 are the main paleo-channels.

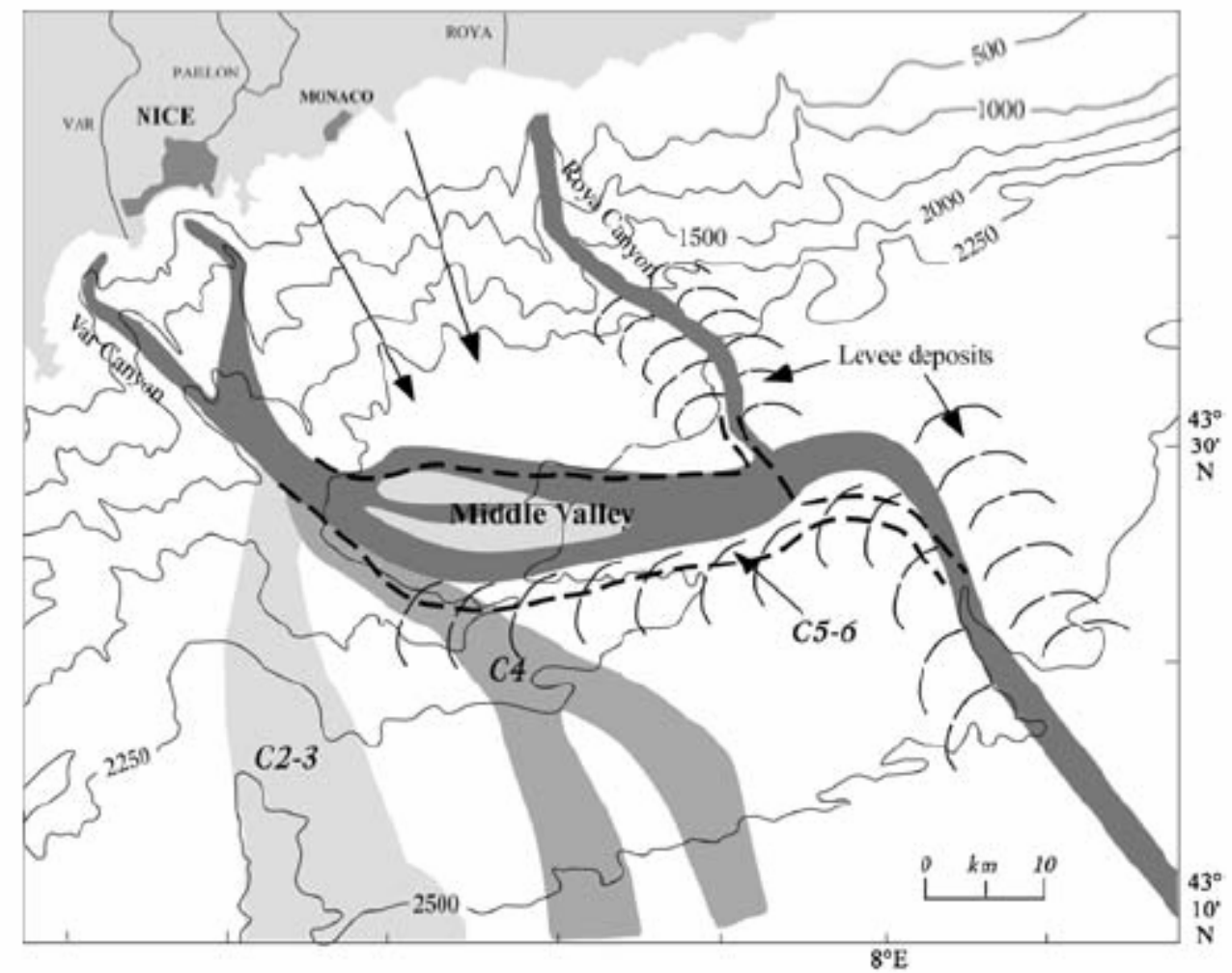

Figure 3 - Profile V11 showing acoustic facies and stratigraphic framework along the Var Sedimentary Ridge. I-IV are regional reflectors (Savoye et al., 1993). C3 and C4 are channels located in Figure 2. Profile location shown in Figure 1.

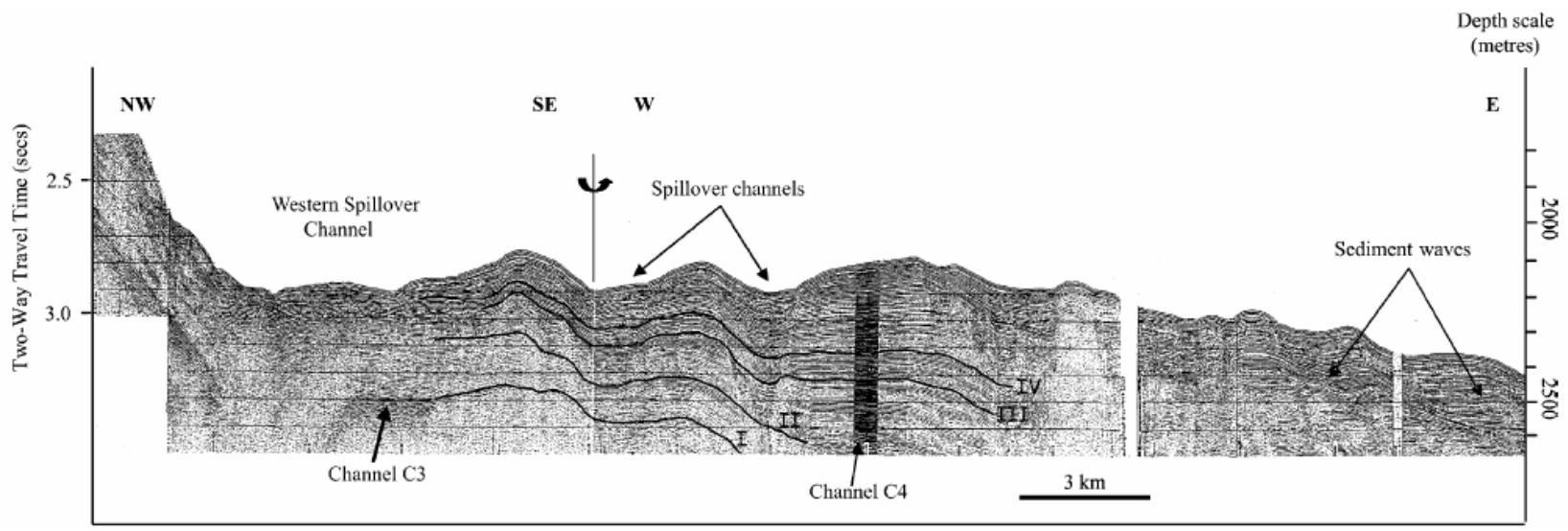


Figure 4 - Profile 03OR103 collected in the middle part of the Var Ridge. Continuous and moderate-amplitude reflections characterising the Ridge deposit appear on top of high-amplitude reflections of channel C4 and correspond to the activity of channel C5-6 and the present-day Var Valley. Sediment waves are observed on the backside of the Ridge. The distal deposits of the Ridge are highly disturbed by salt diapirs (D). Profile location shown in Figure 1.

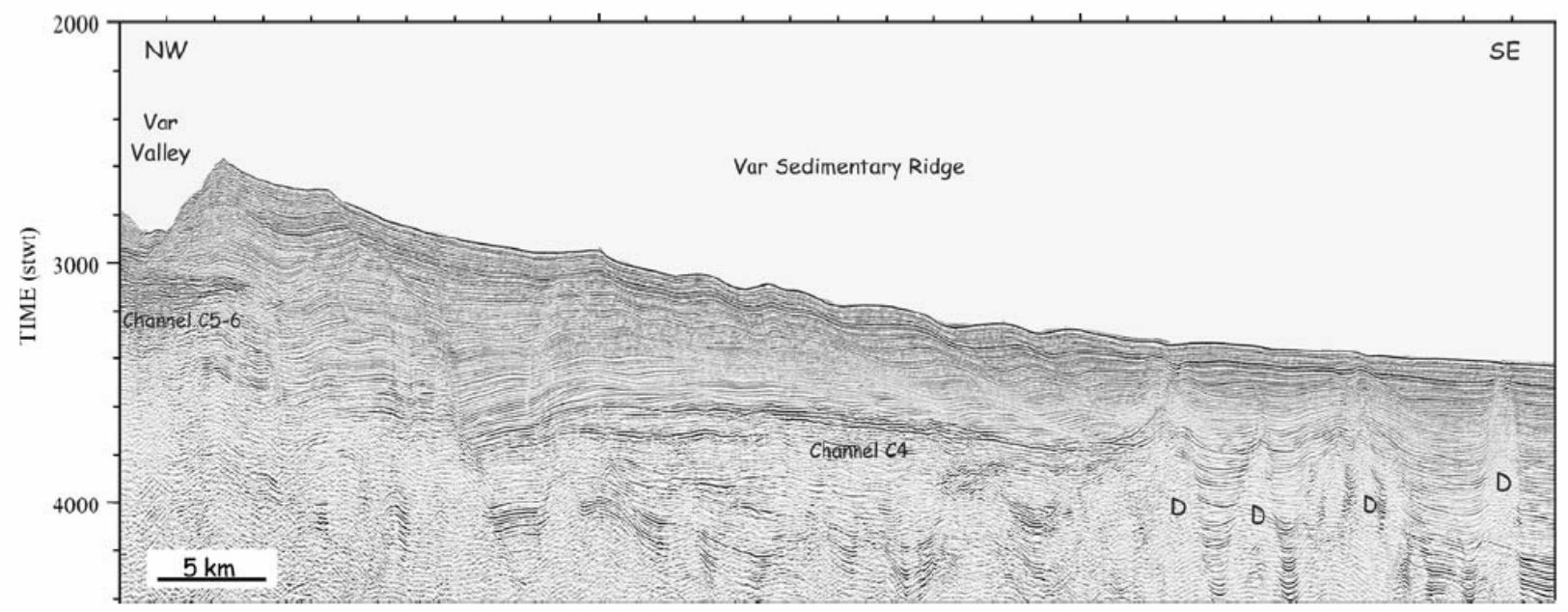

Figure 5 - Detail part of profile $030 R 103$ showing erosional and faulting processes affecting deposits near the crest of the Ridge.

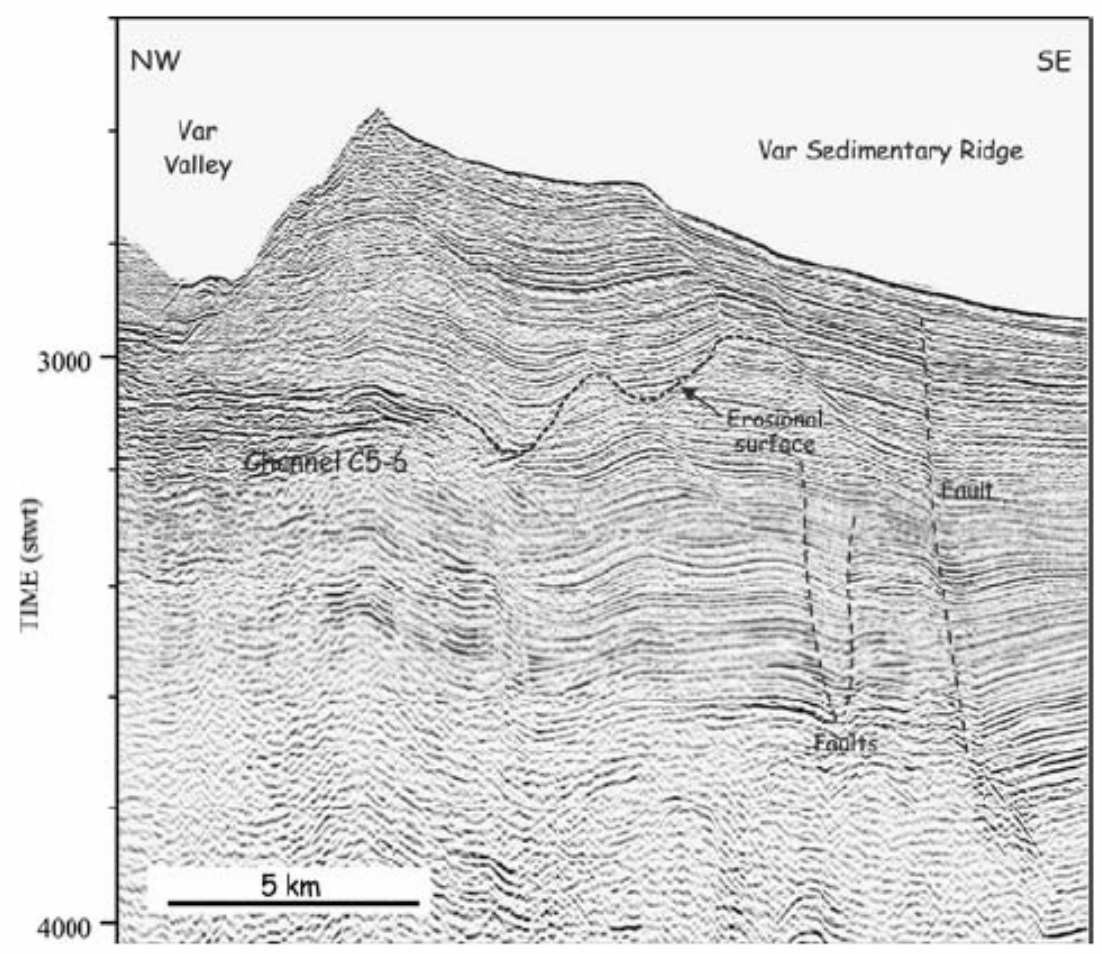


Figure 6 - Detail part of profile 03OR103 showing a gradual change of morphology and evolution of sediment waves through time. Sediment waves directly initiated on top of the channel C4.

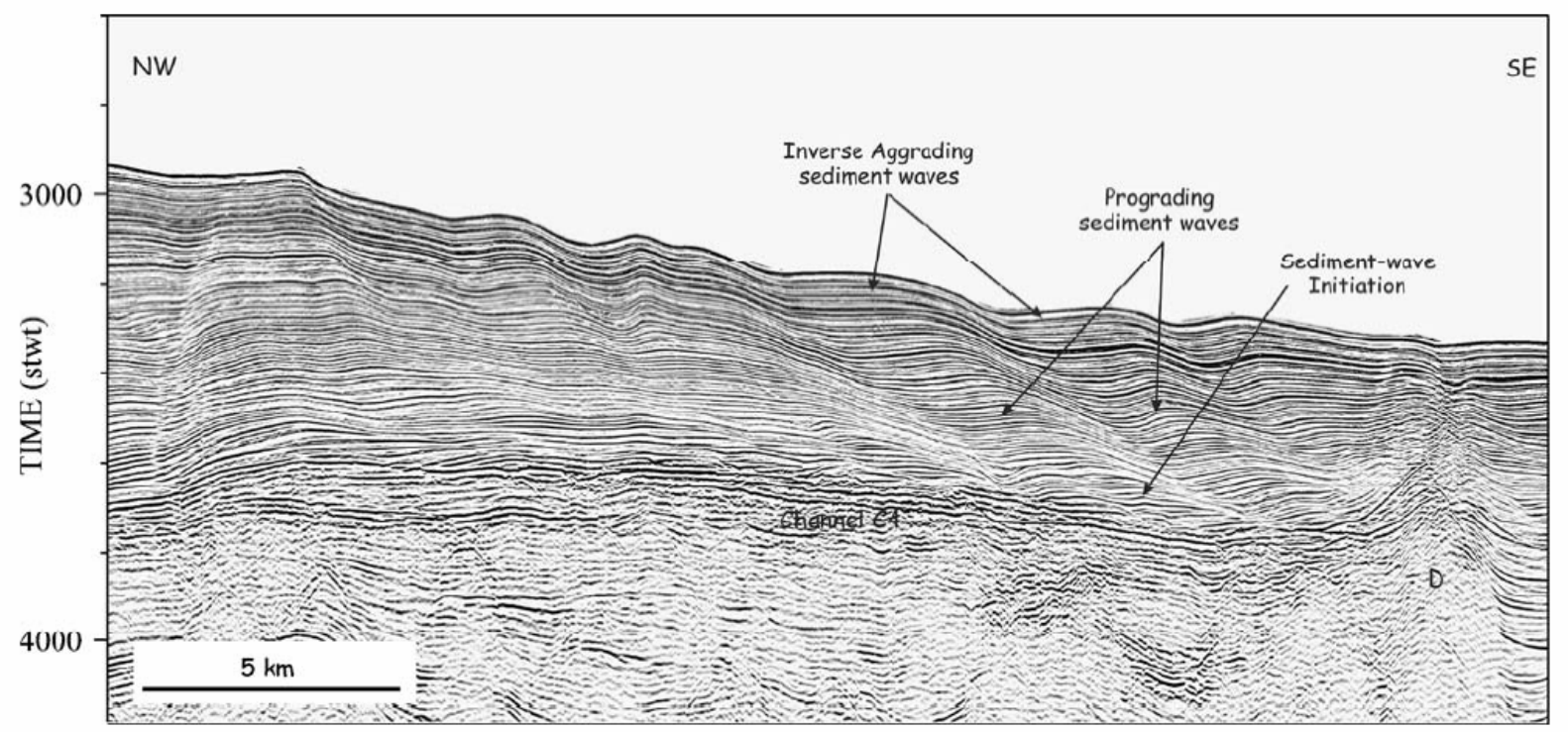

Figure 7 - Distribution of surficial sediment along the Var Sedimentary Ridge. (A), (B) and (C) are schematic cross-sections illustrating the inferred grain-size patterns of the turbidity currents (1, $2,3,4)$ that would overtop the levee at different locations along the valley.
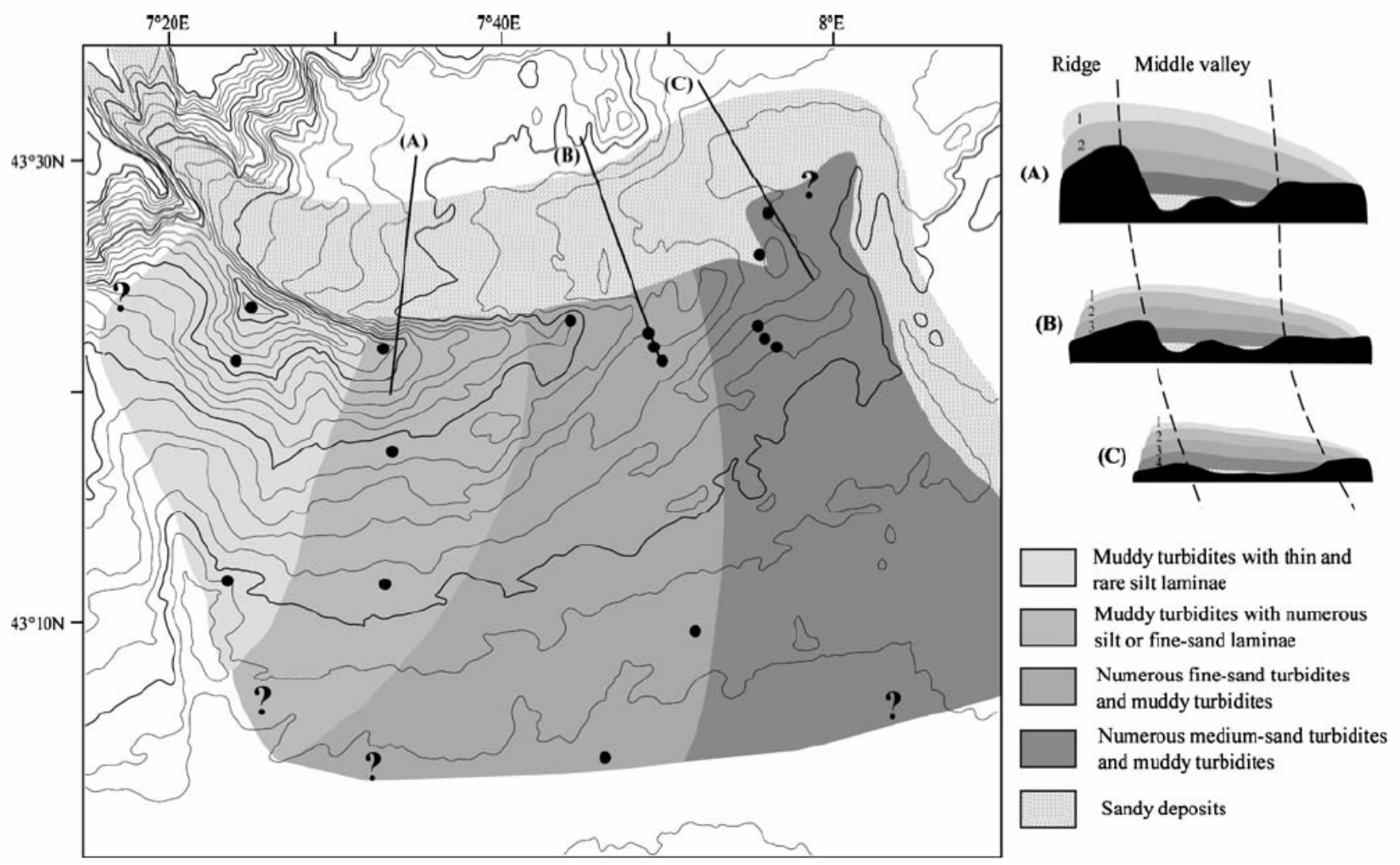
Figure 8 - Profile 04GM101 showing asymmetrical prograding sediment waves across the eastern part of the Ridge. Deposition (D) mainly occurs on the upstream flanks while erosion (E) and lower deposition are predominant on the downstream flanks. Profile location shown in Figure 1.

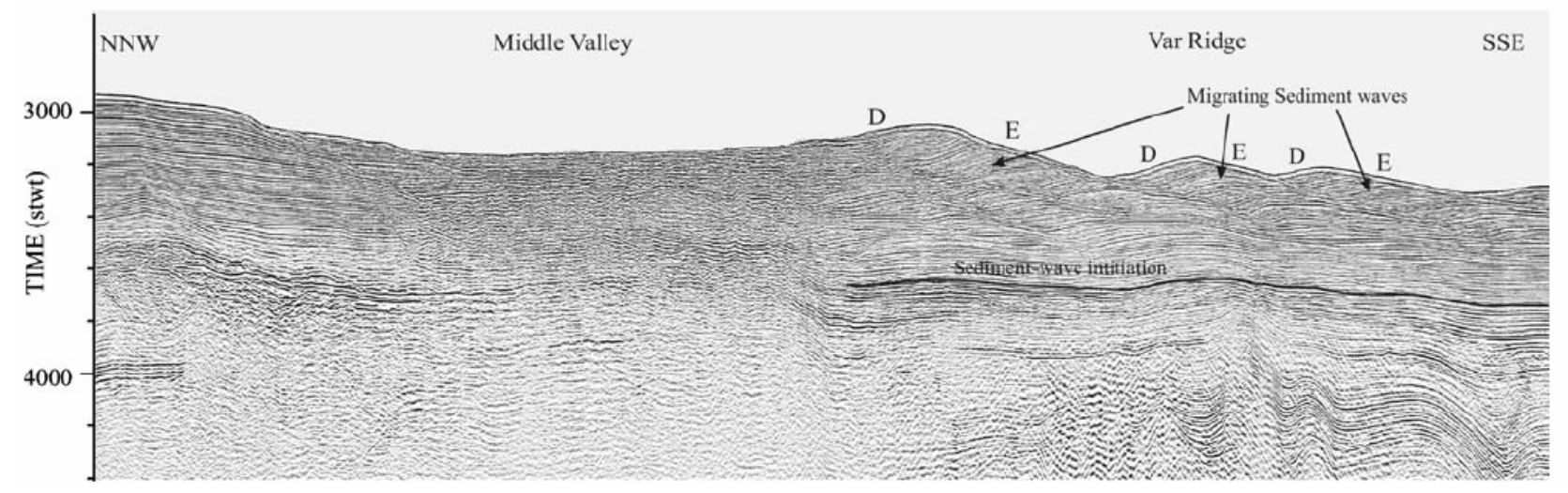

